\title{
Identification of Five Phytonematode Species Associated with Forage Legumes
}

\author{
Mahfouz M. M. Abd-Elgawad"; Mohamed F.M. Eissa ; Abd-Elmoneim Y. \\ El-Gindi ${ }^{* *}$; Grover C. Smart ${ }^{* * *}$; and Ahmed El-bahrawy ${ }^{* * * *}$. \\ * Plant Pathology Department, National Research Centre. \\ ** Department of Agricultural Zoology and Nematology, Faculty of Agriculture, University of \\ Cairo, Giza, Egypt. \\ *** Department of Entomology and Nematology, IFAS, University of Florida, USA. \\ $* * * *$ Institute for Sustainable Plant Protection, National Council of Research, Bari, Italy.
}

\begin{abstract}
Five species of plant parasitic nematodes were present in soil samples planted with forage legumes at Florida, USA. The found species Meloidogyne arenaria, M. incognita, M. javanica, Pratylenchus brachyurus and Tylenchorhynchus martini were depicted in this study. These species belong to order Rhabditida and to taxonomical families Hoplolaimidae (subfamily Meloidogyninae: Meloidogyne arenaria, M. incognita and M. javanica), Pratylenchidae (Pratylenchus brachyurus) and Dolichodoridae (Tylenchorhynchus martini). The identification of the processed specimens was based on the classical taxonomy, following perineal pattern characters for species of Meloidogyne as well as morphological and morphometrical characters in the species specific identification keys for Pratylenchus brachyurus and Tylenchorhynchus martini.
\end{abstract}

Keywords: Meloidogyne arenairia, M. incognita, M. javanica, Pratylenchus brachyurus, Tylenchorhynchus martini, morphology, species description.

\section{Introduction}

The capability of legumes to fix and provide sufficient nitrogen for crop production has encouraged re-appraisal of cropping systems and integrated pest management programs concerning relevant forage legumes. Forage legumes possess some of the best quality forages for livestock since they are palatable, help maintain proper functioning of the ruminant digestive processes and stimulate high production of both meat and milk. However, plant-parasitic nematodes (PPNs) can considerably damage forage legumes (e.g. Baltensperger et al., 1985a, b). Therefore, PPNs identification has its strength in agricultural applications because of its economic participation in nematode management implications. Factually, PPN species delimitation methods in the context of agricultural and health-related applications are more refined at the species and below species level than methods 
employed in nematode biodiversity studies. Yet, both groups of studies help in better understanding of nematology and its interaction with relevant disciplines (Mekete et al., 2012). Identification of PPN populations associated with forage legumes are imperative not only for choosing adequate management control strategies against such plant parasites but also for avoiding spreading of any exotic nematodes in quarantine materials. Yet, PPNs are arduous group to be identified due to their tiny sizes and the difficulties in observing key diagnostic characters/features under conventional light microscope (Carneiro et al., 2017). In addition, the differences of some of these morphological and morphometric characters are subtle, subjective, and have overlapping characters or show intraspecific variation which compromise proper identification or may lead to erroneous identity of the species (Oliveira et al., 2011; Ye et al., 2015; Carneiro et al., 2017). Clearly, nematode identification based on traditional morphology requires well trained and experienced nematode taxonomists which are in decline these days due to lack of interest of young scientists in classical taxonomy (Carneiro et al., 2017). The present study targets the identification of plant-parasitic nematodes associated with fourteen forage legume cultivars planted in Florida, USA.

\section{Materials and Methods}

The experiment was established at the main Agronomy Farm, Gainesville, Florida, USA. Each plot measured $2.1 \times 6.1 \mathrm{~m}(7 \times 20 \mathrm{ft})$ with each forage legume cultivar and the fallow control replicated four times. The soil type is Arredondo fine sand. The plots had been planted to pigeon pea, Cajanus cajan, for eight months and then left fallow for four months before the experiment was established. The experiment, set up initially to test forage cultivars, had been established in a randomized block design with clover cultivars and controls as treatments. The sampled fourteen clover cultivars comprised 'Florida' red clover, 'Nolin' red clover, 'Kenland' red clover, 'Kenstar' red clover, 'Tibbee' crimson clover, 'Dixie' crimson clover, 'Mt. Barker' Subterranean clover, 'Amclo' arrowleaf clover, 'FL - 77' alfalfa, 'Abon' persian clover, 'Wood ford' big flower vetch, 'Seqrest' ball clover, 'Kondinin' rose clover, and 'Chief' crimson clover). Phytonematodes associated with the forage legumes of these experiments were reported to the generic level (Abd-Elgawad et al., 2017). For further identification to species level, about five $2.5-\mathrm{cm}$ diameter cores were taken randomly within the root zone (upper $15-20 \mathrm{~cm}$ ) from each plot and then mixed thoroughly to form one sample representing the plot. Each sample was placed in a plastic bag, stored in an ice chest, and transported to the nematology laboratory. Samples not processed immediately were stored at $10 \pm 1$ ${ }^{0} \mathrm{C}$ until processed. Nematodes were extracted from $100 \mathrm{~cm}^{3}$ soil from each sample using a centrifugal-flotation technique (Caveness and Jensen, 1955), placed in vials, and stored in a refrigerator at $4^{\circ} \mathrm{C}$ for no more than three days until identified to genera and counted. Thereafter, some of the nematodes extracted from the study (Abd-Elgawad et al., 2017) were taken and processed for identification to the 
species level. Laboratory methods for mounting the nematodes and preparing perineal patterns of root-knot nematodes (RKNs) as described by Goodey (1963) and Taylor et al., (1955), respectively were carried out. Three percent formalin was used for making temporary mounts of nematodes and Zut ${ }^{\circledR}$ slide-ringing compound was used to seal the slides. Drawings were made with the camera lucida technique equipped to the microscope. All measurements except ratios are expressed in $\mu \mathrm{m}$ as means \pm standard deviation. Drawings and photogrophs illustrated by Taylor and Sasser (1978) were used for identifying the perineal patterns of Meloidogyne spp. Fifty perineal patterns of each population of Meloidogyne were examined. Key references of Loof (1978), and Tarjan (1973) were consulted to identify species Pratylenchus and Tylenchorhynchus, respectively. A magnification of $1000 \mathrm{x}$ was used to identify all nematodes. Throughout these identifications, we adopted the systematic scheme of De Ley and Blaxter (2002) for the higher classification which has been updated where appropriate by Decraemer and Hunt (2013) to reflect new taxa proposals.

\section{Results and Discussions}

Five species related to three genera of plant-parasitic nematodes associated with all the above-mentioned clover cultivars were identified as Meloidogyne arenaria, M. incognita, M. javanica, Pratylenchus brachyurus and Tylenchorhynchus martini. Measurements and drawings of nematode species are presented in Tables (1-2) and Figures (1-3); respectively. Golden (1971) classified the genera and higher categories of the order Tylenchida in which all of these nematodes are placed. Nevertheless, Tylenchida is no longer present (now it is Rhabditida). In fact, recent molecular phylogenetic analyses recognize 12 clades within the Nematoda, with plant-parasitic taxa located in the basic clade I (Trichodoridae) and clade II (Longidoridae) and in the more advanced clade 12 with the Tylenchomorpha (Holterman et al., 2006; Decraemer and Hunt, 2013).

The perineal pattern of $M$. arenaria (Fig. 1-a) has a rounded to flattened arch, smooth to wavy striae, slightly indented at lateral lines and forking and short irregular striae near the lateral lines. The perineal pattern of $M$. incognita (Fig. 1-b) is elongated with a more or less fattened dorsal arch, striae are smooth to wavy with some forking at lateral lines. The perineal pattern of M. javanica (Fig. 1-c) has a dorsal arch rounded to flattened with distinct lateral lines and few striae extending unbroken from dorsal to ventral sector. The perineal patterns of the adult females of Meloidogyne arenaria, M. incognita, and $M$. javanica were in a complete agreement with the description of those species as reported by Taylor and Sasser (1978).

Although nematodes belonging to the genus Pratylenchus spp. are easy to recognize, species identification is difficult. Loof (1978) wondered why taxonomists merged $P$. brachyurus into $P$. pratensis since the former has a longer stylet than the latter. $P$. brachyurus has two lip annules, angular outer margin of lip region and 
smooth terminus of female tail in addition to the long stylet. Males of this species are very rare, so females have usually empty spermathecae.

Males of Tylenchorhynchus martini were not found in the soil samples. However, the characters of the females corresponded to the holotype by Fielding (1956) and the re-description of Timm (1963) in the following: cuticle with prominent annules, four incisures on the body, lip region set off by slight constriction, three annules on lip region, nerve ring encircling esophagus midway between median bulb and basal bulb, ovaries outstretched and variable number of annules in tail region (17-23), some partly subdivided. The tail of our specimens was never clavate which agreed with Timm report (1963).

While some variations occurred in dimensions between the typotype and the studied specimens, for each nematode species identified, they fit in general in the species descriptions. However, the morphometric identification carried out herein neither negates the need for molecular tools for its documentation nor declines the presence of other PPN species (Abd-Elgawad et al., 2018). According to Decraemer and Hunt (2013), these species belong to order Rhabditida and to taxonomical families Hoplolaimidae (Meloidogyne arenaria, $M$. incognita and $M$. javanica), Pratylenchidae (Pratylenchus brachyurus) and Dolichodoridae (Tylenchorhynchus martini).

The most economically damaging PPNs, such as RKN species (Meloidogyne arenaria, M. incognita, and $M$. javanica) and root lesion nematode (Pratylenchus brachyurus) identified herein are traditionally considered to belong to the order Tylenchida. More recently, molecular data in combination with morphological features have been used to help resolve nematode classification problems. De Ley and Blaxter (2002) provided one classification of nematodes in which the Tylenchida PPNs mentioned above were placed in the infraorder Tylenchomorpha. Their classification is used in the present study and elsewhere (e.g., Decraemer and Hunt, 2013; Sun et al., 2014; Abd-Elgawad et al., 2018). Tylenchomorpha belongs to the suborder Tylenchina within the order Rhabditida. However, the molecular information supporting classification of PPNs is relatively limited. Therefore, Sun et al. (2014) stressed that research on molecular data from more different species is urgently needed for improved classification. Two main classifications have been suggested for RKNs as an economically important PPN group. Firstly, Maggenti et al. (1987) placed RKN in the subfamily Meloidogyninae within the family Heteroderidae belonging to the suborder Tylenchina. Secondly, Siddiqi (2000) placed RKNs in the family Meloidogynidae within the suborder Hoplolaimina. However, several molecular phylogenies based on rDNA show that RKN are closely related to some Pratylenchidae nematodes (RybarczykMydłowska et al., 2013). Based on mitochondrial genome of Meloidogyne graminicola, Sun et al. (2014) suggested that root-knot nematodes have a closer relationship to Pratylenchidae nematodes than to cyst nematodes. In our present study, we adopted the classification of Decraemer and Hunt (2013). 
Table (1): Measurements and ratios of females of Pratylenchus brachyurus associated with forage legumes.

\begin{tabular}{lccc}
\hline \multirow{2}{*}{ Body regions and organs } & \multicolumn{2}{c}{ Dimensions $(\boldsymbol{\mu m})$ and ratios } & $(\mathbf{n}=\mathbf{1 3})$ \\
\cline { 2 - 4 } & Minimum & Maximum & Average \pm S.D. \\
\hline Body length & 342 & 579 & $441 \pm 39$ \\
Body diameter & 23 & 29 & 26 \\
Tail length & 18 & 27 & $21 \pm 5.9$ \\
Anal body diameter & 7 & 10 & 8 \\
Stylet length & 17 & 24 & $20 \pm 4.3$ \\
Esophagus length & 68 & 82 & 72 \\
Distance from head to vulva & 308 & 491 & 422 \\
A ratio & 15 & 20 & --- \\
B ratio & 5 & 7 & --- \\
C ratio & 19 & 21 & --- \\
Ć ratio & 2.6 & 2.7 & -- \\
V\% & $83 \%$ & $90 \%$ & --- \\
\hline
\end{tabular}

Table (2): Measurements and ratios of females of Tylenchorhynchus martini associated with forage legumes.

\begin{tabular}{lccc}
\hline \multirow{2}{*}{ Body regions and organs } & \multicolumn{2}{c}{ Dimensions $(\boldsymbol{\mu m})$ and ratios } & $(\mathbf{n}=\mathbf{1 3})$ \\
\cline { 2 - 4 } & Minimum & Maximum & Average \pm S.D. \\
\hline Body length & 603 & 772 & $705 \pm 122$ \\
Body diameter & 23 & 28 & 25 \\
Tail length & 42 & 59 & $49 \pm 13.4$ \\
Anal body diameter & 14 & 19 & 17 \\
Stylet length & 18 & 24 & $21 \pm 5.3$ \\
Esophagus length & 131 & 156 & 142 \\
Distance from head to vulva & 326 & 432 & 379 \\
A ratio & 26 & 33.2 & --- \\
B ratio & 4.6 & 5.1 & --- \\
C ratio & 13.1 & 14.3 & --- \\
Ć ratio & 3 & 3.1 & --- \\
V\% & $54 \%$ & $56 \%$ & --- \\
\hline
\end{tabular}




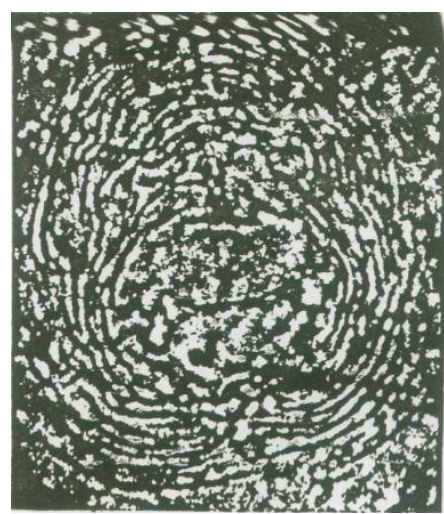

(A)

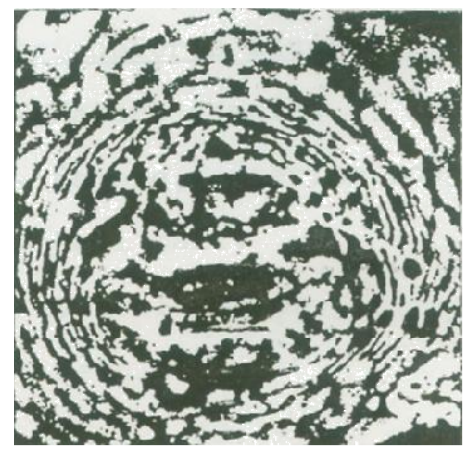

(B)

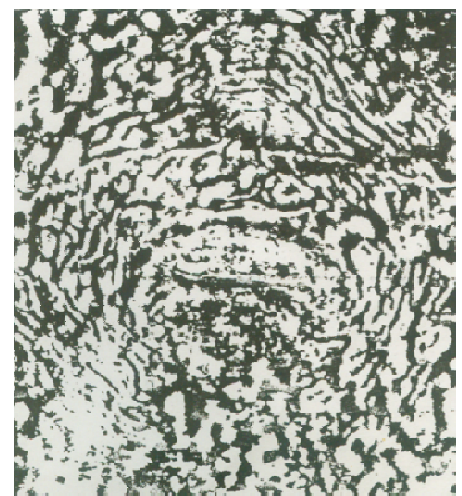

(C)

Fig. (1): Photographs of perineal patterns of root-knot nematodes.

(A) Meloidogyne arenaria, (Neal, 1 889) Chitwood, 1949.

(B) M. incognita (Kofoid \& White, 1919) Chitwood, 1949.

(C) M. Javanica (Treub, 1885) Chitwood, 1949. 


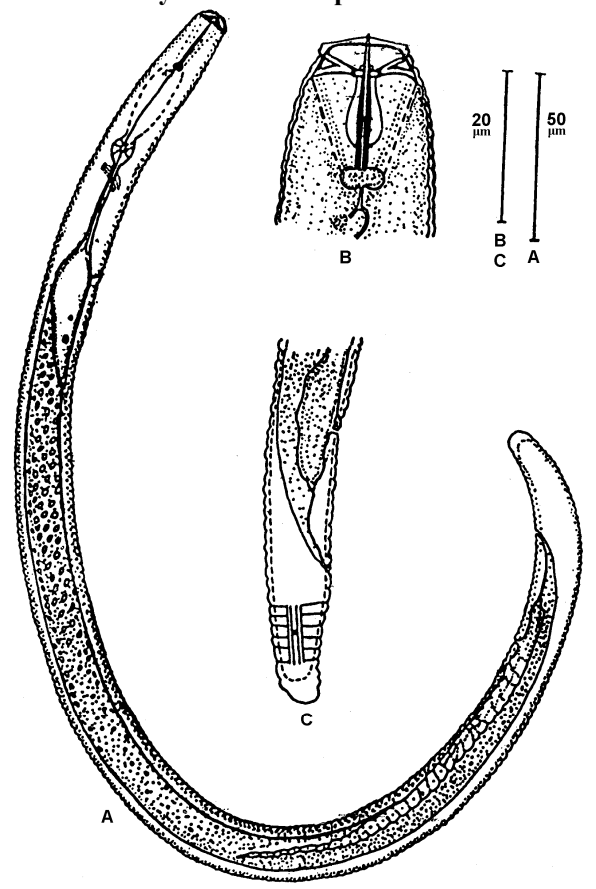

Fig. (2): Pratylenchus brachyurus (Godfrey, 1929) Filipjev \& Schuurmans Stekhoven, 1941.

(A) Mature female, (B) Head region, (C) Female tail.
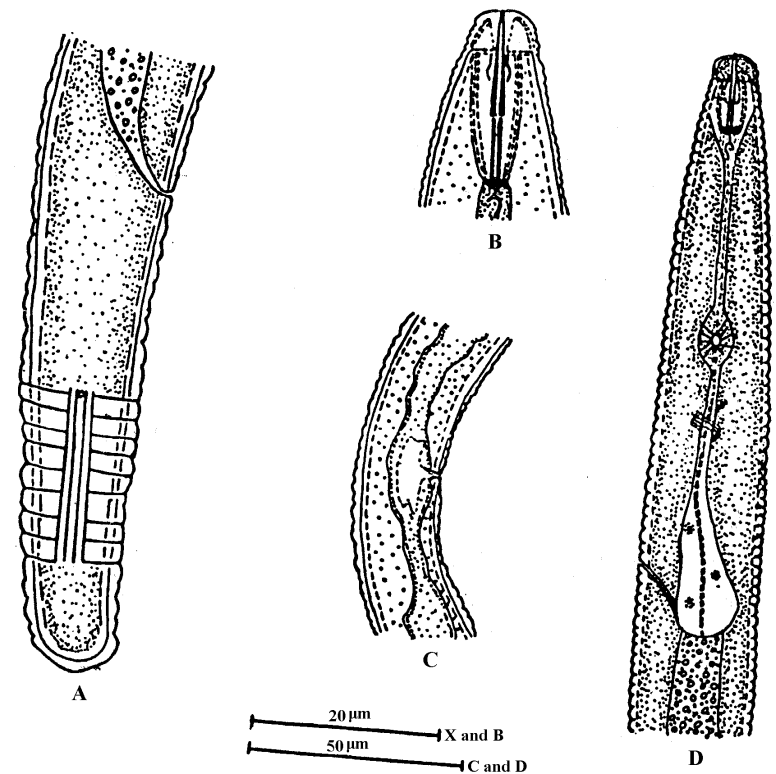

Fig. (3): Tylenchorhynchus martini, Fielding, 1956.

(A) Female tail, (B) Head region, (C) Vulval region, (D) Anterior body region.

\section{Acknowledgement}


This study was supported in part by the NRC In-house project entitled 'Pesticide alternatives against soilborne pathogens attacking legume cultivation in Egypt'.

\section{References}

Abd-Elgawad, M.M.M., Eissa, M.F.M., El-Gindi A.Y., and Smart, G.C. (2017). Development of plant-parasitic nematode populations on forage crops under field conditions. Egyptian Journal of Agronematology 16(2): 50-61.

Abd-Elgawad, M.M.M., Eissa, M.F.M., El-Gindi A.Y., Smart, G.C. and Elbahrawy, A. (2018). Description and identification of four species of plantparasitic nematodes associated with forage legumes. Egyptian Journal of Agronematology 17(1): In press.

Baltensperger, D.D., Quesenberry, K.H., Homer, E.S., Dunn, R.A. and AbdElgawad, M.M. (1985a). Interaction of alfalfa recurrent phenotypic selection cycles with root-knot nematodes. Soil and Crop Science Society of Florida Proceedings. 44, 162-164.

Baltensperger, D. D., Quesenberry, K. H., Dunn, R. A. and Abd-Elgawad, M. M. (1985b). Root-knot nematode interaction with berseem clover and other temperate forage legumes. Crop Science 25, 848-851.

Carneiro, R.M.D.G., Silva, F.S.O., Correia, V.R. (2017). Methods and tools currently used for the identification of plant parasitic nematodes. In: Nematology- Concepts, diagnosis and control. Shah, M.M. and Mahamood, M.(eds), pp. 19-35, Rijeka, Croatia, InTech Open, DOI: 10.5772/66851.

Caveness, F.E and Jensen, H.J. (1955). Modification of the centrifugal-flotation technique for the isolation and concentration of nematodes and their eggs in soil. Proceedings of the Helminthological Society of Washington 22: 8789.

De Ley, P. and Blaxter, M.L. (2002). 1. Systematic position and phylogeny. In: Biology of Nematodes. Lee, D. (Ed.), pp. 1-30. The Harwood Academic Publishers, Reading, UK.

Decraemer, W. and Hunt, D.J. (2013). Structure and classification. In: Plant Nematology, 2nd edn. Perry, R.N. and Moens, M. (eds), pp. 3-39. CAB International, Wallingford, UK.

Fielding, M.J. (1956). Tylenchorhynchus martini, a new nematode species found in the sugar cane and rice fields of Louisiana and Texas. Proceedings of the Helminthological Society of Washington 23: 47-48.

Golden, A. M. (1971). Classification of the genus and higher categories of the order Tylenchida (Nematoda). In: Plant parasitic nematodes. Vol. 1. Zuckerman, 
B. M., Mai, W. F. and R. A. Rohde (eds), pp. 191-232. Academic Press, New York.

Goodey, J.B. (1963). Laboratory methods for work with plant and soil nematodes. Ministry Agric., Fish. and Food. Tech. Bull. No. 2, London, 72 pp.

Holterman, M., van der Wurff, A., van den Elsen. S., van Megen, H., Bongers, T., Holovachov, O., Bakker, J. and Helder, J. (2006). Phylum-wide analysis of SSU rDNA reveals deep phylogenetic relationships among nematodes and accelerated evolution toward crown clades. Molecular Biology and Evolution 23:1792-1800.

Loof, P.A.A. (1978). The genus Pratylenchus Filipjev,1936 (Nematoda: Pratylenchidae): A review of its anatomy, morphology, distribution, systematics and identification. Sveriges Lantbruksuniversitet Vaxtskyddsrapporter, Jordbruk 5:1-50.

Maggenti, A.R., Luc, M., Raski, D., Fortuner, R., and Geraert, E. (1987). A reappraisal of Tylenchina (Nemata). 2. Classification of the suborder Tylenchina (Nemata: Diplogasteria). Revue De Nematologie 10: 135-142.

Mekete, T., Dababat, A., Sekora, N., Akyazi, F., and Abebe, E. (2012). Identification key for agriculturally important plant-parasitic nematodes Prepared for the International Nematode Diagnosis and Identification Course 2012 - A manual for nematology. Mexico, D.F.: CIMMYT.

Oliveira, C.M.G., Monteiro, A.R., and Blok, V.C. (2011). Morphological and molecular diagnostics for plant parasitic nematodes: Working together to get the identification done. Tropical Plant Pathology 36(2): 065-073

Rybarczyk-Mydłowska, K., van Megen, H., van den Elsen, S., Mooyman, P., Karssen, G., et al. (2013). Both SSU rDNA and RNA polymerase II data recognize that root-knot nematodes arose from migratory Pratylenchidae, but probably not from one of the economically high-impact lesion nematodes. Nematology 16:125-136.

Siddiqi, M.R. (2000). Tylenchida: parasites of plants and insects. Second edition. CABI Publishing, Wallingford, UK, $833 \mathrm{p}$.

Sun, L., Zhuo, K., Lin, B., Wang, H., and Liao, J. (2014). The Complete Mitochondrial Genome of Meloidogyne graminicola (Tylenchina): A Unique Gene Arrangement and Its Phylogenetic Implications. PLoS ONE 9(6): e98558. doi:10.1371/journal.pone.0098558

Tarjan, A. C. (1973). A synopsis of the genera and species in the Tylenchorhynchinae (Tylenchoidea, Nematoda). Proceedings of the Helminthological Society of Washington 40:123-144.

Taylor, A.L. and Sasser, J.N. (1978). Bilogy, identification and control of root-knot 
nematodes (Meloidogyne spp.) Raleigh, North Carolina State Univ. Graphics, NC, USA.

Taylor, A.L., Dropkin, V. H., and Martin, G. C. (1955). Perineal patterns of rootknot nematodes. Phytopathology 45:26-34.

Timm, R.W. (1963). Tylenchorhynchus trilineatus n. sp. from West Pakistan with notes on T. nudus and T. martini. Nematologica 9: 262-266.

Ye, W., Zeng, Y., and Kerns, J. (2015). Molecular characterisation and diagnosis of root-knot nematodes (Meloidogyne spp.) from Turfgrasses in North Carolina, USA. PLoS One. 10(11):e0143556. DOI: 10.1371/journal.pone. 0143556 


\section{تعريف خمسة أنواع من النيماتودا المتطفلة نباتيًّا المرتبطة بالبقوليات العلفية}

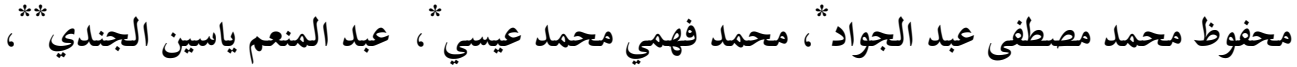

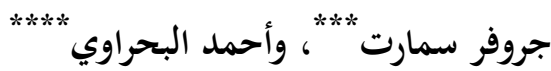

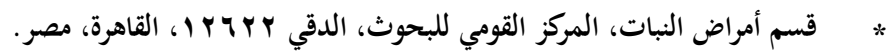

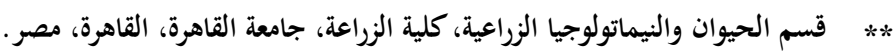
***** ق قسم الحشرات والنيماتولوجي، معهد علوم الغذاء والزراعة، جامعة فلوريدا، الولايات المتحدة الأمريكية. ***** معهد الوقاية المستدامة للنبات، المجلس القومي للبحوث، مدينة باري، إيطاليا.

\section{الملخص العربي}

تم تعريف خمسة أنواع من النيماتودا المتطفلة نباتيًّا الموجودة في عينات التربة المنزرعة

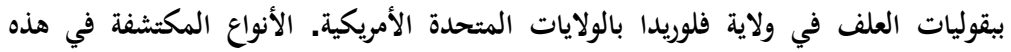

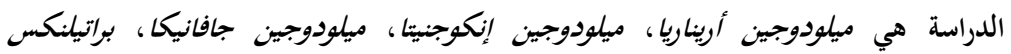

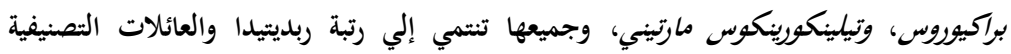
هوبلوليميداي (تحت العائلة ميلويدوجيناي: ميلودوجين أريناريا ، ميلودوجين إنكوجنيتيا ، ميلودوجين واريني

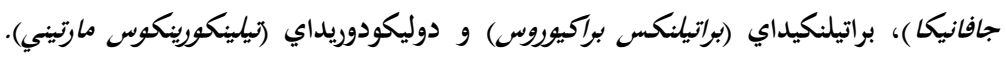

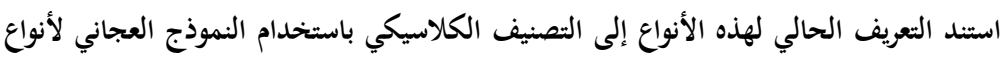

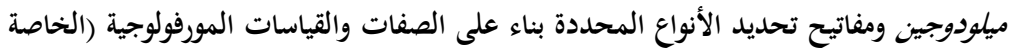
بالشكل الظاهري) للنوعين براتيلنكس براكيوروس، و تيلينكورينكوس مارتيني.

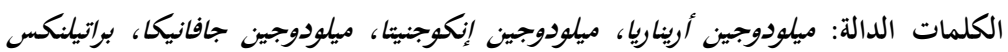

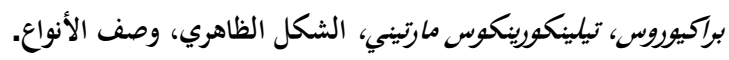

